\title{
PENDEKATAN RELIGIUS YANG DIGUNAKAN SISWA MI DALAM MENJELASKAN FENOMENA ALAM
}

\author{
Dici Rizka Anditia \\ dici.r.anditia@gmail.com \\ Universitas Majalengka
}

\begin{abstract}
ABSTRAK
Penelitian ini mendeskripsikan pendekatan religius yang digunakan siswa Madrasah Ibtidaiyah Al-Inayah kelas satu sampai dengan kelas enam ketika menjelaskan fenomena alam. Tujuan penelitian ini yaitu untuk mengetahui pendekatan yang digunakan siswa dengan latar belakang sekolah Madrasah Ibtidaiyah. Serta untuk mengetahui perbedaan pendekatan yang digunakan siswa pada setiap jenjang kelas. Penelitian ini dilatarbelakangi oleh konsep pembelajaran IPA yang diperoleh dari hasil penyelidikan fenomena yang terjadi di alam, namun masyarakat seringkali memandang fenomena alam yang dianggap tidak lazim dengan sudut pandang non ilmiah. Media seringkali mempublikasikan fenomena alam yang dikaitkan dengan mitos. Masyarakat dan media mempunyai peran yang sangat berpengaruh terhadap konsep berpikir siswa. Metode yang digunakan dalam penelitian ini adalah kualitatif deskriptif. Data yang dikumpulkan untuk menjawab pertanyaan penelitian yaitu hasil tes siswa mengenai fenomena alam yang diperkuat dengan wawancara. Hasil tes menunjukkan Siswa dominan menggunakan pendekatan religius, semakin tinggi jenjang kelas semakin tinggi penggunaan pendekatan religiusnya. Hal ini menunjukkan siswa belum menjadikan pendekatan ilmiah sebagai dasar utama pemecahan masalah sains. Siswa dengan latar belakang Madrasah Ibtidaiyah sebagian besar menggunakan sudut pandang religius dalam menjelaskan fenomena sains, pendekatan ilmiah harus terus diberi penguatan oleh guru karena fenomena alam yang berkaitan dengan sains dapat dijadikan dasar berpikir ilmiah.
\end{abstract}

Kata Kunci : Pendekatan Religius, Menjelaskan Fenomena alam.

\footnotetext{
${ }^{1}$ Penulis adalah dosen tetap Prodi PGSD Fakultas Pendidikan Dasar dan Menengah Universitas Majalengka
} 


\section{PENDAHULUAN}

\section{Latar belakang masalah}

Ilmu Pengetahuan Alam merupakan ilmu-ilmu kealaman (natural science). IPA merupakan pengetahuan ilmiah yang diperoleh dari hasil penyelidikan mengenai fenomena yang terjadi di alam. IPA tidak hanya mengajarkan siswa mengenai fakta, teori, atau fungsi alam bagi manusia, tetapi juga mengajarkan bagaimana cara para ahli sebelumnya mendapatkan konsep mengenai alam tersebut, serta bagaimana cara kita mengadopsi sikap ilmiah para ilmuan dalam mendapatkan suatu teori. Hal ini berkaitan dengan Natural of Science yaitu sains sebagai produk, sains sebagai proses, dan sains sebagai sikap. Sains adalah ilmu yang berasal dari alam, dan alam sangat dekat dengan peserta didik. teori yang dihasilkan dapat diaplikasikan oleh siswa dalam kehidupan sehari-hari.

Sebelum sains diajarkan secara formal siswa SD sebenarnya sudah mengenal konsep dasar sains berdasarkan fenomena alam yang mereka alami dalam kehidupan sehari-hari. Tubuh yang hangat saat terkena matahari, mata tidak dapat melihat tanpa cahaya, melihat gerhana bulan dan matahari, dll. konsep sains tersebut perlu diberi penguatan oleh guru melalui pembelajaran yang bermakna. Pada saat siswa mengalami peristiwa yang berhubungan dengan fenomena alam sebetulnya terdapat banyak pertanyaan dalam pikiran mereka, dengan mengkonstruk pemikiran siswa diharapkan pertanyaan yang merupakan masalah bagi siswa dapat terungkap dan pertanyaan mereka dapat dijawab melalui pendekatan yang ilmiah.

Tantangan pembelajaran pada abad ke 21 fokus kepada konstruktivis belajar adalah penemuan, konsep dibangun melalui asimilasi dan akomodasi. Pengetahuan tidak sekedar ditransformasikan tetapi juga diinterpretasi untuk menghasilkan ilmu baru dan pelajar dilatih berpikir kritis, berpikir kreatif, kolaboratif dan mampu menkomunikasikan suatu ilmu dengan baik. Hal ini berdasarkan study literatur $P$. C. Ifegho (2012, h. 76) yaitu:

Teacher of science education in the $21 s t$ century should accept the contemporary view of NOS to ensure successful inculcation of the 21st century learning skills to the primary science learner and to enable them face the scientific and technological challenges for sustainable development.

Pada hakikatnya pembelajaran IPA tidak dapat dipisahkan dengan pendekatan ilmiah. Apa pun kurikulumnya, IPA adalah ilmu pengetahuan yang diperoleh dari prosedur ilmiah. Pendekatan ilmiah dan metode ilmiah merupakan solusi untuk memperoleh ilmu pengetahuan. Harapan tersebut berbanding terbalik dengan kenyataan di lapangan. Kurikulum IPA pada Madrasah Ibtidaiyah maupun Sekolah Dasar pada dasarnya mengajarkan konten yang sama. Akan tetapi perbedaan lingkungan MI dengan Sekolah yang lainnya menitikberatkan nilai religius. Pada hal ini peneliti tidak mempertentangkan Sains dengan nilai religius. Akan tetapi peneliti ingin mengetahui seberapa besar persentase pendekatan religius yang diunakan siswa di MI dan keajegan cara berpikir ilmiah siswa kelas satu sampai dengan enam. Hal ini sesuai dengan penjelasan (Yeo and John, 2014:1902):

We found that such a construction involves the complex coordination of different types of signs, not only to represent the entities in the phenomenon, but also to support thinking and reasoning about it at abstract levels. Scientific conventions and rules, and everyday material and social tools were found to be crucial in shifting from one level of abstraction to another. The findings highlight the 
importance of developing the skillful use of schemes of scientific representation by students and familiarizing them with commonly encountered contexts.

Fenomena Sains erat kaitannya dengan pengalaman siswa dalam kehidupan seharihari. Hasil penelitian pada jenjang SMA dapat menjadi bahan refleksi guru atau tenaga kependidikan jenjang Sekolah Dasar. Siswa yang diperkenalkan konsep berpikir dengan Pendekatan ilmiah sejak dini akan memperkuat pola berpikir ilmiah pada jenjang sekolah berikutnya. Fenomena Sains menuntut siswa untuk berpikir ilmiah. Pembelajaran melalui pendekatan dan metode ilmiah seharusnya dapat menjadikan siswa berpikir berdasarkan pendekatan atau sudut pandang yang ilmiah. Konsep IPA memang dapat diciptakan sendiri oleh siswa berdasarkan pengalaman masingmasing, namun konsep IPA yang didapat sendiri oleh siswa tersebut harus diluruskan oleh guru agar tidak terjadi Miskonsepsi. Konsep Sains yang didapat dari pengalaman pribadi siswa dipengaruhi oleh interaksi siswa dengan teman, keluarga, dan masyarakat disekitarnya. Hal ini menyebabkan siswa belum konsisten dalam berpikir yang berlandaskan pendekatan ilmiah.

Konsep berpikir masyarakat ketika menemukan fenomena Sains yang dianggap tidak lazim baik secara langsung maupun melalui media seringkali dihubungkan dengan pendekatan atau sudut pandang yang bersifat non ilmiah. Media seringkali menghubungkan fenomena Sains dengan hal-hal yang bersifat non ilmiah. Masyarakat dan media sangat berpengaruh terhadap konsep berpikir siswa. Hal ini berdasarkan pendapat Mikulak (2011:202) bahwa:

Throughout these public controversies, the media have played a specific and influential role as mediator between scientist and layperson. Indeed, journalists play a large part in filtering and shaping scientific messages as they are delivered to their intended audience.

Siswa yang menggunakan pendekatan ilmiah, mitos yang berkembang di masyarakat mengenai fenomena alam dapat meningkatkan rasa ingin tahu dan melakukan proses penalaran menggunakan metode ilmiah. Rendahnya prestasi siswa Indonesia di bidang Sains menandakan diperlukannya suatu penelitian apakah pendekatan ilmiah sudah menjadi pola pikir yang konsisten ketika menjelaskan fenomena Sains dengan tidak terpengaruh pendapat masyarakat atau media yang tidak ilmiah. Atau siswa menjelaskan fenomena alam tersebut dari pendekatan lain yang bersifat non ilmiah. Berdasarkan latar belakang diatas peneliti bermaksud untuk melakukan riset berkenaan dengan "Pendekatan yang digunakan siswa dalam Menjelaskan Fenomena Alam".

\section{Rumusan masalah}

1. Bagaimanakah pendekatan religius yang digunakan siswa Madrasah Ibtidaiyah Al-Inayah?

2. Apakah ada perubahan pendekatan yang digunakan oleh siswa kelas 1 , $2,3,4,5$, dan 6 ?

\section{Manfaat penelitian}

Setelah mengetahui hasil analisis pendekatan religius yang digunakan oleh siswa dalam menjelaskan fenomena sains diharapkan dapat menjadi bahan refleksi bagi guru dan tenaga kependidikan di Indonesia. Melalui penelitian ini dapat diketahui apakah pendekatan ilmiah sudah menjadi pola pikir siswa atau siswa masih menggunakan pendekatan lain yan bersifat non ilmiah. Dengan demikian diharapkan pembelajaran IPA dapat membentuk cara berpikir ilmiah yang dapat dijadikan sebagai pemecahan masalah secara ilmiah terutama ketika menghadapi fenomena alam yang dianggap tidak lazim di lingkungan masyarakat. 


\section{LANDASAN TEORI}

\section{Pendekatan sebagai sudut pandang}

Pengertian pendekatan dalam Kamus Besar Bahasa Indonesia adalah "proses, perbuatan, atau cara mendekati". Pendekatan dapat dikatakan sebagai sudut pandang seseorang dalam memandang suatu hal. berbeda dengan pengertian pendekatan dalam konteks pembelajaran yaitu "landasan filosofi yang melatarbelakangi proses pembelajaran"(Wisudawati dan Eka, 2014, h.106).

Ketika menghadapi fenomena alam yang baru ditemui siswa atau dianggap tidak lazim pengetahuan siswa sebelumnya sangat mempengaruhi proses interpretasi siswa tersebut dalam menjelaskan fenomena alam yang mereka temukan. Hal ini sesuai dengan temuan hasil penelitian Park (2006, h. 488) yaitu:

In this study, it is found that the background knowledge played a particularly important role in generating a new theoretical hypothesis involving the theoretical causal relationship, while displacing prior ideas. In this case, similarity based reasoning is useful in connecting the background knowledge and the conflicting phenomena to be explained. Even though some students did not have the necessary background knowledge, by virtue of the relevant experiences, they could generate a new experiential hypothesis using similarity-based reasoning between the relevant experiences and the conflicting phenomena.

Penelitian tersebut menemukan latar belakang pengetahuan memainkan peran sangat penting dalam menghasilkan hipotesis teoritis baru yang melibatkan hubungan kausal teoritis, sementara menggusur ide-ide sebelumnya. Dalam hal ini, penalaran berbasis kesamaan berguna dalam menghubungkan latar belakang pengetahuan dan fenomena yang bertentangan untuk dijelaskan. Meskipun beberapa siswa tidak memiliki latar belakang pengetahuan yang diperlukan, berdasarkan pengalaman yang relevan, mereka bisa menghasilkan hipotesis pengalaman baru menggunakan penalaran berbasis kesamaan antara yang relevan pengalaman dan fenomena yang bertentangan.

Park menemukan hipotesis teoritis baru dipengaruhi oleh pengetahuan siswa sebelumnya dan siswa cenderung akan mengabaikan ide-ide sebelumnya. Siswa dapat menghasilkan hipotesis dari pengalaman yang baru ditemukan dengan menggunakan penalaran terhadap fenomena yang bertentangan bagi siswa. Contohnya ketika siswa menemukan manusia berkaki gajah. Tentunya fenomena ini bertentangan dengan pengalaman siswa yang biasa menemukan manusia dengan ukuran kaki yang normal. Hipotesis siswa akan beragam karena akan dipengaruhi pengetahuan sebelumnya dan lingkungan sekitar siswa. Bagi siswa yang tinggal dilingkungan yang kental akan mitos yang mengandung mistis bisa saja siswa tersebut menganggap bahwa manusia tersebut terkena sihir.

Menurut Thorndike dan Skinner (Suyitno, 2015: h.101) "Perilaku manusia adalah hasil pembentukan melalui kondisi lingkungan" lingkungan mempunyai peranan penting dalam pembentukan kepribadian siswa, sehingga guru perlu memberikan penguatan melalui contoh nyata dilapangan. Jadi dapat disimpulkan, selain pengaruh pengetahuan siswa sebelumnya, lingkungan juga dapat menjadi faktor penentu pendekatan yang akan digunakan siswa sebagai pola pikir.

\section{Pendekatan Religius}

Dugaan mengenai faktor penyebab fenomena alam dengan sudut pandang agama yang diyakini siswa. Ada beberapa kata yang menjadi ciri siswa menggunakan 
pendekatan religius yaitu dosa, takdir baik, takdir buruk, kualat, karma dari Allah, kurang amal. Siswa yang menggunakan pendekatan religius berpikir berdasarkan keyakinan (keimanan). Siswa lebih mengutamakan keyakinannya terhadap segala sesuatu yang diajarkan dalam agama yang diyakininya terlebih dahulu sebelum proses pemahaman yang lebih lanjut.

Terdapat perbedaan antara pandangan ilmu pengetahuan IPA dengan Agama. Pendidikan IPA mengajarkan siswa belajar berpikir ilmiah, melalui pembelajaran siswa diajarkan ilmu pengetahuan yang bersumber dari alam dan bidang kajiannya bersifat empiris. Hal ini sesuai dengan pendapat Anshari dalam Susanto (2014, h. 123) "Ilmu pengetahuan atau ilmu adalah usaha pemahaman manusia mengenai kegiatan, struktur, pembagian, hukum tentang hal ikhwal yang diselidiki melalui penginderaan dan dibuktikan kebenarannya melalui riset".

Sedangkan bidang kajian agama adalah metafisik dan sumber agama berasal dari Tuhan. Agama berasal dari bahasa Sansekerta berasal dari kata a dan gama. A berarti "Tidak" dan gama berarti "Kacau". Jadi kata agama diartikan tidak kacau, tidak semrawut hidup menjadi lurus dan benar Susanto (2014, h. 125). Dapat dikatakan ilmu pengetahuan mengajarkan kebenaran sedangkan agama mengajarkan kebenaran yang hakiki.

Penelitian yang dilakukan oleh Christopherp Scheitle dilatarbelakangi oleh agama dan ilmu masing-masing membuat klaim tentang realitas atau kebenaran dan karena klaim masing-masing sering berbeda. Konflik ini berdampak terhadap pribadi sebagai individu dipaksa untuk memilih salah satu versi kebenaran. Hal ini berdasarkan pendapat Russell dalam Scheitle (2011, h. 176):

The assumption is that religion and science each make claims about reality or truth and, because their respective claims often differ, they must be in conflict with each other.
This conflict has both personal consequences as individuals are forced to choose one version of the truth.

Christopherp Scheitle melakukan penelitian di 236 kampus kepada 112000 mahasiswa mengenai persepsi mereka terhadap agama dan ilmu pengetahuan hasilnya $27,4 \%$ pendapat mereka menitikberatkan pada agama dan $70 \%$ lainnya tidak memihak keduanya atau kolaborasi antar keduanya, kemudian empat tahun kemudian melakukan survey lanjutan kepada 36000 dari jumlah sebelumnya dan hanya 14.527 yang menanggapi. Hasil survey 53,2\% konsisten terhadap pendapatnya, $46,8 \%$ berubah. $45,9 \%$ pendapat mahasiswa berubah dengan mengkolaborasikan agama dan ilmu pengetahuan sedangkan $0,9 \%$ berubah dengan lebih menitikberatkan agama. Hasil penelitian mengenai hubungan agamasains dengan bidang studi menghasilkan pendapat mahasiswa menitikberatkan pada tidak memilih agama dan ilmu pengetahuan atau mengkolaborasikan keduanya meskipun mereka memiliki tingkat religius yang rendah. Termasuk mahasiswa bidang Ilmu Pengetahuan Alam 9,5 menitikberatkan pada Agama, 20,2\% ilmu pengetahuan, dan $70,3 \%$ tidak memilih keduanya/mengkolaborasikannya.

Berdasarkan penelitian tersebut dapat disimpulkan hubungan agama dan ilmu pengetahuan dipandang sebagai kedua aspek yang dapat dikolaborasikan tanpa memperdebatkan menjadi suatu konflik diantara keduanya. Kembal ke karakteristik berpikir ilmiah harus ditanamkan sejak dini, karena agama didasarkan dengan keyakinan seringkali masyarakat lebih menitikberatkan penjelasan berbasis agama. Ilmu pengetahuan termasuk IPA menuntut peserta didik untuk terus berinovasi untuk menemukan teori baru, sedangkan agama sebagai pembimbing manusia agar bahagia dunia dan akhirat. Misalnya, Tsunami dalam Konteks agama adalah cobaan Tuhan dan sekaligus rancangan-Nya tentang alam secara 
keseluruhan. Oleh karena itu, manusia harus bersabar atas cobaan tersebut dan mencari hikmah yang terkandung dibalik Tsunami. Adapun menurut ilmu pengetahuan, Tsunami terjadi akibat pergeseran lempengan bumi, oleh karena itu para ilmuwan harus mencari ilmu pengetahuan untuk mendeteksi kapan tsunami akan terjadi dan bahkan kalau perlu mencari cara mengatasinya.

Indonesia memiliki enam agama yang diakui dalam UUD 1945 yakni Islam, Katholik, Protestan, Hindu, Budha, Konghuchu. Diyakini semua agama mengajarkan hal-hal yang baik. Menurut Al-Ghazali dalam Umar (2010, h. 87) "Tugas pendidik dalam pendidikan Islam adalah menyempurnakan, membersihkan, menyucikan, serta membimbing hati manusia untuk mendekatkan diri (taqarrub) kepada Allah". Jika dihubungkan dengan penelitian Christopherp Scheitle? Perbedaan sudaut pandang Sains dan Agama tidak perlu menjadi sesuatu hal yang diperdebatkan, keduanya dapat berjalan beriringan. Sebagai contoh dalam siswa yang Sekolah yang kental akan budaya Islam yaitu Sekolah Dasar Islam Terpadu atau Pesantren ajaran agama akan lebih ditekankan dibanding sekolah negri pada umumnya.

Pandangan siswa ketika menemui fenomena Sains secara tidak langsung terhubung dengan kepercayaan terhadap ajaran agama siswa tersebut. Namun, tugas guru juga harus mengarahkan siswa berpikir seimbang antara pengetahuan religiusnya dengan pola berpikir ilmiah yang mengarahkan siswa berpikir dengan mengkonstruk pengetahuan sebelumnya dan dihubungkan dengan fakta empiris, sehinggan ketika siswa menemukan fenomena Alam hipotesis siswa mengarah ke hipotesis ilmiah bukan sekedar akal sehat siswa.

Menurut Suyitno (2015: h.14) "Keberagamaan merupakan salah satu karakteristik esensial eksistensi manusia yang terungkap dalam bentuk pengakuan atau keyakinan akan kebenaran suatu agama yang diwujudkan dalam sikap dan perilakunya". Kebenaran mengenai agama sudah dirasakan siswa SD karena penenaman kepercayaan akan Tuhan sejak dini diperkenalkan oleh orang tuanya, hal ini sejalan dengan pendapat Yusuf (2008: h.183) "Kualitas keagamaan anak dipengaruhi oleh proses pembentukan atau pendidikan yang diterimanya".

\section{METODE PENELITIAN}

Penelitian deskriptif adalah suatu bentuk penelitian yang paling dasar, ditujukan untuk mendeskripsikan atau menggambarkan fenomena-fenomena yang ada, baik yang bersifat alamiah ataupun rekayasa manusia. Penelitian ini mengkaji bentuk, aktivitas, karakteristik, perubahan, hubungan, kesamaan dan perbedaannya dengan fenomena lain (sukmadinata, 2013 h.72). Penelitian ini mengkaji mengenai pendekatan-pendekatan yang digunakan siswa dalam menjelaskan berbagai macam fenomena alam yang terdapat dalam soal. Peneliti menganalisis berdasarkan jawaban siswa yang dipertegas dengan hasil wawancara dengan siswa tersebut.

Penelitian ini melibatkan siswa kelas satu sampai dengan kelas enam, berikut data setiap kelas siswa MI Al-Inayah:

\begin{tabular}{|c|c|}
\hline Kelas & Jumlah Siswa \\
\hline 1 & 18 \\
\hline 2 & 25 \\
\hline 3 & 26 \\
\hline 4 & 28 \\
\hline 5 & 23 \\
\hline 6 & 21 \\
\hline Jumlah & 141 \\
\hline
\end{tabular}

Instrumen yang digunakan dalam penelitian ini yaitu adalah instrumen tes tertulis yang berisi cerita mengenai fenomena alam dan siswa diminta untuk menanggapi cerita fenomena alam tersebut sesuai pendapatnya. Instrumen tes terdiri dari tujuh soal mengenai fenomena alam yang berbeda-beda 
Peneliti melakukan pengumpulan data berdasarkan hasil tes jawaban siswa dan wawancara berdasarkan soal. Siswa kelas satu dan dua teknik pengumpulan datanya dilakukan dengan wawancara langsung, yaitu peneliti membacakan soal kepada siswa dan siswa langsung menjawabnya. Hal ini dilatarbelakangi oleh masih banyak siswa kelas satu dan dua di MI Al-Inayah yang belum bisa membaca. Proses analisis data diawali dengan mempersentasekan pendekatan siswa menggunakan tabel rekapitulasi yang digunakan siswa pada setiap kelas.

\section{Hasil Penelitian}

Gambaran umum pendekatan religius yang digunakan siswa SD di MI ALInayah sebesar $35,7 \%$. Siswa MI AlInayah berjumlah 141 siswa, pendekatan religius dominan digunakan siswa ketika siswa dihadapi soal mengenai fenomena alam. Siswa MI Al-Inayah berada di lingkungan sekolah yang sistem pembelajarannya menitkberatkan nilainilai religius. MI Al-Inayah berada ditengah perkampungan padat penduduk. Interaksi siswa di lingkungan yang religius membuat pola pikir yang berdasar sudut pandang religius juga.

Berikut contoh jawaban SN kelas 5 yang menggunakan pendekatan religius:

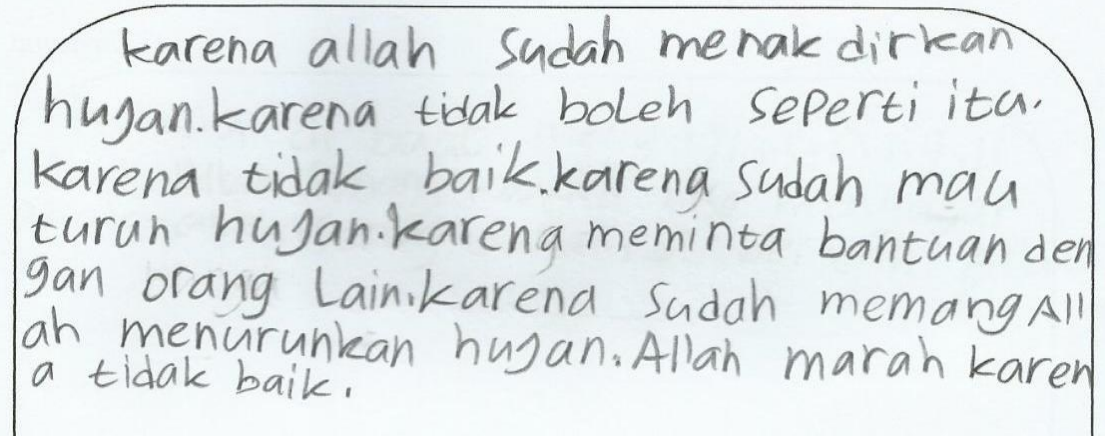

Berikut contoh jawaban NS kelas 6 yang menggunakan pendekatan religius:

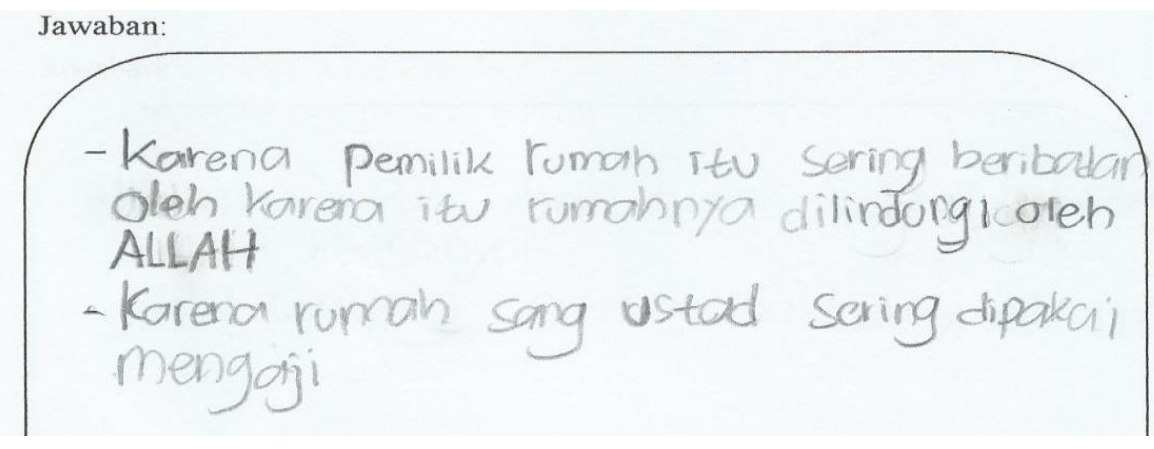

Berikut contoh jawaban SZ kelas 5 yang menggunakan pendekatan ilmiah dan religius: Jawaban:

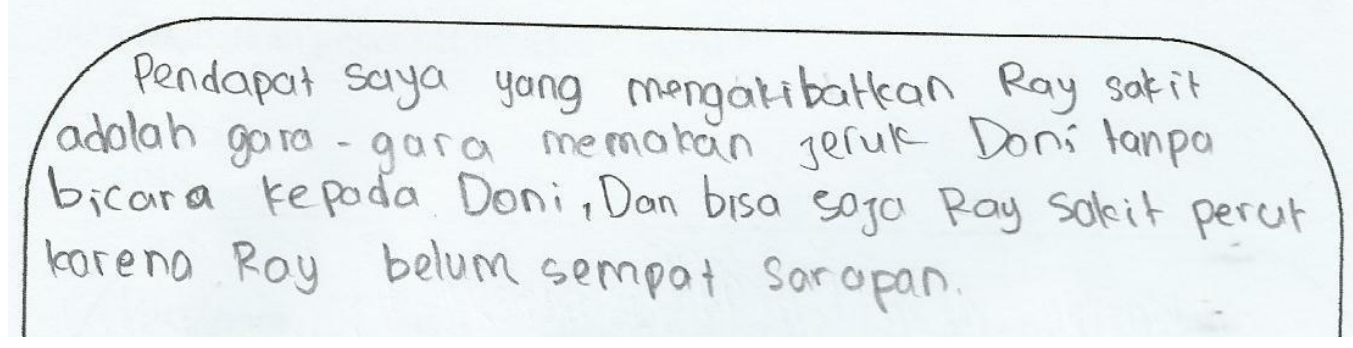


Berikut perubahan pendekatan religius siswa MI Al-Inayah kelas satu sampai dengan enam:

\begin{tabular}{|l|c|}
\hline Kelas & $\begin{array}{c}\text { \% Jumlah } \\
\text { Siswa }\end{array}$ \\
\hline 1 & 27 \\
\hline 2 & 33 \\
\hline 3 & 43 \\
\hline 4 & 34 \\
\hline 5 & 46 \\
\hline 6 & 29 \\
\hline Jumlah & 141 \\
\hline
\end{tabular}

Berdasarkan data tersebut terlihat semakin tinggi jenjang kelas sudut pandang siswa semakin non ilmiah, siswa MI Al-Inayah memadukan pola pikirnya dengan sudut pandang religius, tabel diatas merupakan persentase siswa yang menggunakan pendekatan religius, selebihnya siswa memadukan pendekatan ilmiah dengan religius. Menggabungkan sudut pandang ilmiah dan religius bukan merupakan hal yang diperbolehkan. Hal ini berdasarkan penelitian Christopherp Scheitle bahwa hubungan agama dan ilmu pengetahuan dipandang sebagai kedua aspek yang dapat dikolaborasikan tanpa memperdebatkan menjadi suatu konflik diantara keduanya.

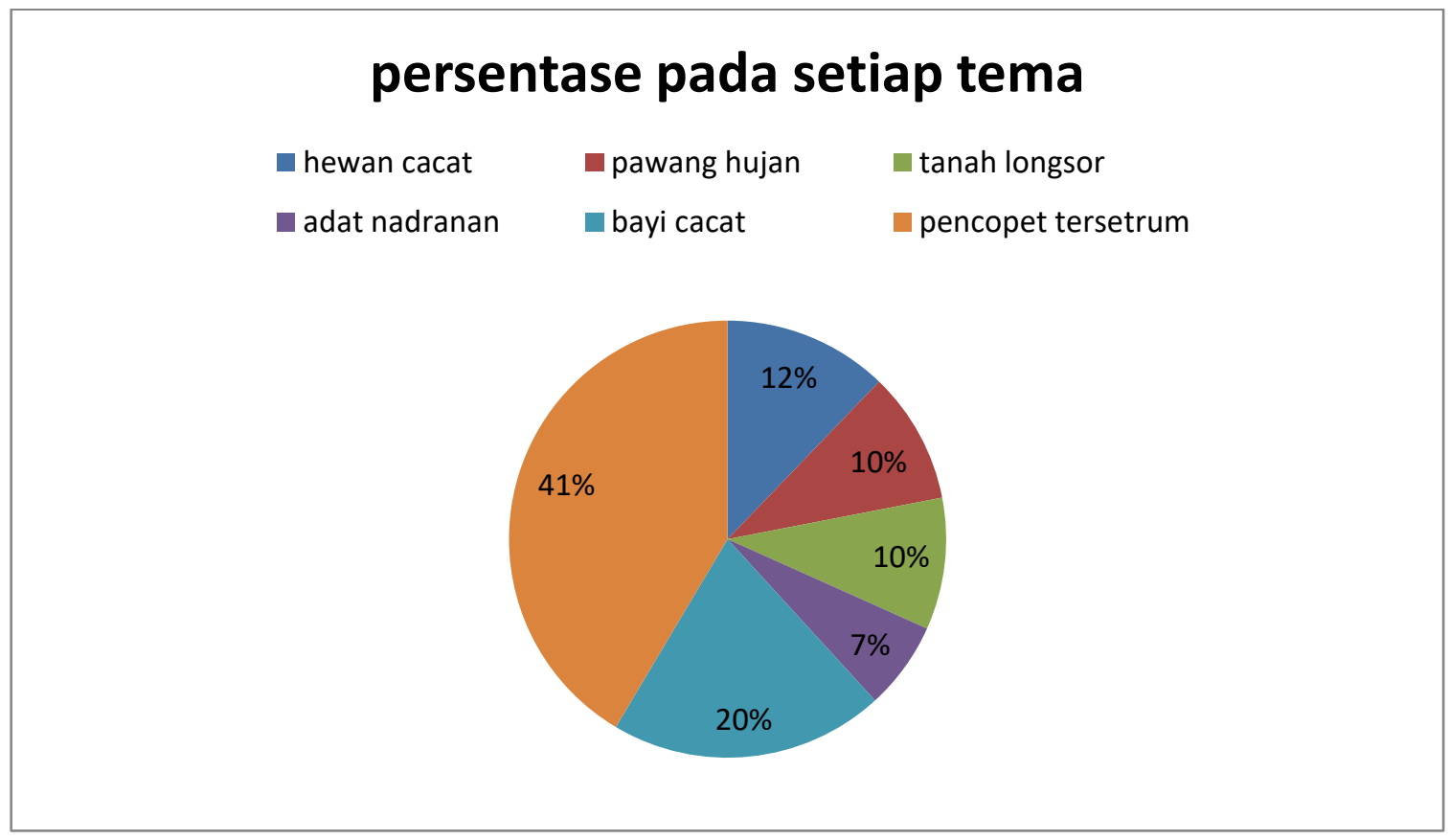

Soal yang diberikan siswa mengenai kambing berkaki tujuh, pawang hujan, bencana tanah longsor, prosesi adat istiadat nadranan atau sedekah bumi, bayi terlahir cacat, dan pencopet tersetrum listrik. Data diatas didukung oleh hasil wawancara perorangan dengan setiap siswa, sangat terlihat penggunaan pendekatan religius masih dominan terutama pada tema pencopet tersetrum listrik. Soal yang diberiikan kepada siswa merupakan fenomena alam dalam kehidupan sehari-hari yang sering dihubungkan dengan pendekatan non ilmiah. Lingkungan yang religius terbukti berpengaruh terhadap pola pikir siswa. Berdasarkan hasil persentase diatas, selebihnya siswa menggunakan pendekatan ilmiah dan religius. Siswa menggabungkan sudut pandang ilmiah dan religiusnya. Selain itu muncul beberapa sudut padang non ilmiah lainnya yang sangat menarik bagi peneliti untuk melakukan penelitian lanjut.

\section{Implikasi}

Berdasarkan hasil pengamatan mengenai pendekatan yang digunakan 
siswa dalam menjelaskan fenomena alam peneliti menemukan persentase penggunaan pendekatan ilmiah semakin menurun pada tingkat kelas yang lebih tinggi. Implikasinya pendekatan ilmiah perlu ditingkatkan dengan metode dan strategi yang dikembangkan oleh guru di sekolah, serta penguatan dari lingkungan keluarga dan sosialnya dalam rangka pencapaian tujuan kurikulum di Indonesia khususnya yang berkaitan dengan materi Sains. Penggunaan pendekatan non ilmiah perlu diminimalisir dengan memberikan contoh pembelajaran yang aplikatif, dalam pembelajaran Sains guru dapat mengembangkan materi pembelajaran melalui fenomena alam yang terjadi di lapangan yang dapat menstimulus pendapat siswa. Diharapkan pendekatan ilmiah dapat menjadi pola pikir siswa dan dasar untuk memecahkan masalah dalam kehidupan sehari-hari.

\section{Daftar Pustaka}

Driana, Elin.2014. Gawat Darurat Pendidikan. Diakses melalui: edukasi.kompas.com. Tanggal akses: 14 Desember 2014.

Mikulak, Anna. 2011. Mismatches between 'Scientific' and 'NonScientific' Ways of Knowing and Their Contributions to Public Understanding of Science. Springer Science+Business Media Integr Psych Behav (2011) 45:201-215 DOI 10.1007/s12124-011-9157-8.

Park, Jongwoon. 2006. Modelling Analysis of Students'Processes of Generating Scientific Explanatory Hypotheses. International Journal of Science Education. Vol. 28, No. 5, 14 April 2006, pp. 469-489.

PC Ifegho. 2012. Strategies For Developing Learning Skills In Primary
Science In Nigeria School. DOI: 10.5901/jesr.2012/v2n8p71.

Scheitle, Christopherp. 2011. U.S. College Students' Perception of Religion and Science: Conflict, Collaboration, or Independence? A Research Note. Journal for Scientific Study Of Religion (2011) 50(1):175-186.

Sukmadinata, Nana. 2013. Metode Penelitian Pendidikan. Bandung: PT Remaja Rosdakarya.

Susanto. 2014. Filsafat Ilmu Suatu Kajian dalam Dimensi Ontologis, Epistemologis, dan Aksiologis. Jakarta: PT Bumi Aksara.

Suyitno, at all. 2008. Landasan Pendidikan. Bandung: Sub Koordinator MKDP Landasan Pendidikan Departemen Pedagogik FIP UPI.

Wisudawati dan Eka. 2014. Metologi Pembelajaran IPA. Jakarta: PT Bumi Aksara.

Yeo and John. 2014. Constructing a Scientific Explanation-A Narrative Account. International Journal of Science Education. Registered Number: 1072954 Registered office: Mortimer House, 37-41 Mortimer Street, London W1T 3JH, UK. DOI: 10.1080/09500693.2014.880527. 